\title{
WRITING LIVES IS MORE THAN WRITING LINES: POSTMODERN PERSPECTIVES ON LIFE WRITING
}

\author{
By Carl Leggo
}

\begin{abstract}
I want to compose the lined and layered art of (a) life. I seek to know the circular, circulatory, and curricular flowing of blood, life, and memory that constitutes the heart of the poet. To live well is to live rooted in the earth, energized by the heart, discerning with the heart. In my life writing I am learning to breathe with the heart's rhythms as I seek to disclose and know again my location situated in local geographical spaces that represent a location for locution in the bigger world. What I really want to promote in this paper is the notion that life writing is more than writing lines-I want to emphasize the energy of memory and emotion and spirit. Life writing is not so much about reviewing as previewing, not so much about looking back as looking forward. Life writing is about hope and seeking health.
\end{abstract}

To be a poet in a destitute time means: to attend, singing, to the trace of the fugitive gods. This is why the poet in the time of the world's night utters the holy. (Heidegger 94)

A poet stands before reality that is every day new, miraculously complex, inexhaustible, and tries to enclose as much of it as possible in words. (Milosz 56)

I have a great deal to say in this paper, and I will say very little, not because I don't want to say more, but simply because I don't know what I mean, know only that I mean to mean more than this meaning.

So, I will offer you only a few words, not because I'm mean, but still only a few poems, a few stories, a few ruminations, a simmering stew of words, hopefully savory, perhaps slavering.

I was born in Corner Brook, Newfoundland, in 1953.

According to the Encyclopedia Britannica Yearbook, in 1953

a census of animals in the Gran Paradiso National Park

found 3,242 marmots and 109 badgers,

Albert Einstein published Generalization of Gravitation Theory,

the sex ratio in Hawaii still showed a considerable excess of males, Mexico granted the vote to women,

President Dwight D. Eisenhower proposed an international agency to pool

atomic energy supplies from both the western and communist worlds for peaceful purposes, world tunnelling activity increased significantly,

a panel discussion on religious art concluded that the eclectic school of religious architecture had lost its influence,

Red Buttons told jokes on TV, and a process was perfected which turns oranges into a powder which may be reconstituted into highly palatable orange juice.

The Encyclopedia Britannica Yearbook does not mention my birth.

In A Letter to a Young Poet Virginia Woolf writes: "All you need now is to stand at the window and let 
your rhythmical sense open and shut, open, and shut, boldly and freely, until one thing melts in another, until the taxis are dancing with the daffodils, until a whole has been made from all these separate fragments.... That perhaps is your task - to find the relation between things that seem incompatible yet have a mysterious affinity, to absorb every experience so that your poem is a whole, not a fragment; to rethink human life into poetry..." (22).

I am also keen to rethink poetry into human life. More and more I find my living and teaching and researching are poem-making_-meandering, lingering, constantly surprised by twists and turns revealing views and vistas that take the breath away and then fill me with oxygen enough to explode the lungs.

I got married on May 13. I re-married Lana who I first met in 1967, and first dated in 1970, and first married in 1974. A few years ago, a long time ago, I destroyed my marriage with Lana, lived with another, wrote stories - destructive and hurtful, knew the world in fearful and terrible colours. Then, I returned to Lana just over a year ago, and now just recently we have spoken new vows, the old vows inadequately honoured, filled with hope that our new vows will write sturdy lines for living well, with wellness, in the world. At the wedding, a friend offered a gift of two words. He said, "To live well takes courage and humility." I have been ruminating on those words, courage and humility, and now I offer them to you as a gift.

Etymologically, "courage" is derived from the Old French word "curer" which means heart. Humility is connected to "humus" which means earth. The words heart and earth have the same letters with just the "h" moved from beginning to end. (Like the poet bpNichol I have a passion for the letter "h.")

Located in the earth,

knowing the heart,

I will learn by heart

the earth's rhythms,

rooted in humility

for forgetting and forgiving,

rooted in courage

for remembering and giving.

As Heidegger once wrote, "Poetry does not fly above and surmount the earth in order to escape it and hover over it. Poetry is what first brings man onto the earth, making him belong to it, and thus brings him into dwelling" (218).

I want to compose the lined and layered art of (a) life. I seek to know the circular, circulatory, and curricular flowing of blood, life, and memory that constitutes the heart of the poet. To live well is to live rooted in the earth, energized by the heart, discerning with the heart. In my life writing I am learning to breathe with the heart's rhythms as I seek to disclose and know again my location situated in local geographical spaces that represent a location for locution in the bigger world.

In Pedagogy of the Heart, published posthumously in 1997, Paulo Freire acknowledges from the perspective of a long life nearing its end that his childhood backyard was a space connected to many spaces. Freire writes: "My childhood backyard has been unveiling itself to many other spaces-spaces that are not necessarily other yards. Spaces where this man of today sees the child of yesterday in himself and learns to see better what he had seen before. To see again what had already been seen before always implies seeing angles that were not perceived before. Thus, a posterior view of the world can be done in a more critical, less naïve, and more rigorous way" (38). Freire encourages me that "the more rooted I am in my location, the more I extend myself to other places so as to become a citizen of the world. No one becomes local from a universal location" (39).

I am learning that the heart of any pedagogic endeavour is learning to breathe. What I really want to promote in this paper is the notion that life writing is more than writing lines-I want to emphasize the 
energy of memory and emotion and spirit. Life writing is not so much about reviewing as previewing, not so much about looking back as looking forward. Life writing is about hope and seeking health.

Ursula Kelly writes: "An apparent paradox has emerged out of the increasing influence of poststructural practice: the intensified attention to auto/biography in education. It is paradoxical in that a genre that has traditionally signaled attention to, and even romanticized, the individual of liberal humanist and modernist thinking - the essentialized authentic and rational self...-seems an unlikely site of popular practice within a theoretical context in which the constitution of self and the origins and authenticity of its narratives are highly contested" (47-48).

$$
\begin{gathered}
\text { Located in the earth, } \\
\text { knowing the heart, } \\
\text { I will learn by heart } \\
\text { the earth's rhythms, } \\
\text { rooted in humility } \\
\text { for forgetting and forgiving, } \\
\text { rooted in courage } \\
\text { for remembering and giving. }
\end{gathered}
$$

Now, seven postmodern perspectives and seven autobiographical poems:

\section{LINE ONE: POSTMODERNISM PROMOTES LANGUAGE AS CONSTITUTIVE.}

$$
\begin{array}{r}
\text { Life writing is not only } \\
\text { recording and reporting and repeating } \\
\text { the lived story as known, } \\
\text { as written by the subject; } \\
\text { life writing is } \\
\text { recoding and restorying and restoring } \\
\text { the lived story as unknown, } \\
\text { as unwritten by the subject. }
\end{array}
$$

Brenda Marshall: "Postmodernism is about language. About how it controls, how it determines meaning, and how we try to exert control through language" (4).

bpNichol: "If the writing is evocative it is only so thru evocation. Which is partly syntax, partly mystery" ( $4)$.

Jane Rule: "A genuine autobiography is usually written by someone who has devoted a great deal of time to language" (32).

\section{WINTER ALPHABET}

returning in March after seven years

of November to January rain

I know only I have forgotten

the winters I grew up with

for a few days I walk in Corner Brook as if I am fighting winter

head down, going somewhere fast

except I move slowly

almost pantomime, pushing myself 
through winter like walking under water

I must learn to lean with winter

seek its erratic rhythms

like a dory sliding up and down

the smooth sides of a rough sea

I taste winter, winter savours

my body with a lustful lover's appetite

snow bites pinches pokes stabs

slices like a set of sharp knives

in a TV infomercial

neatly skinning a tomato

snow acts with verb exuberance,

a veritable thesaurus of action words

winter reduces the world

people stay home more

huddle in their cars more

hide in shopping malls more

deep snow, hard-packed snow,

plowed snow, powder snow

no hint of spring anywhere

except spring always comes

sunglasses essential, blind colour,

light and shadow tear the retina

snow in mountain creases

and cracks, a monochrome world

like the alphabet on paper,

a text I am learning to read again

reminded how quickly I grew

illiterate, lost my language

LINE TWO: POSTMODERNISM PROMOTES THE SUBJECT AS A CONSTRUCT, ALWAYS IN

PROCESS, A MATRIX OF IDENTITIES.

When I name myself or when I am named by others, I am created (constructed or written) with identities, and these identities are multiple

because I always occupy many subject positions: teacher, poet, father, son, husband, believer, long-haired white Canadian middle-aged man from Newfoundland. I have written myself and been written in multiple identities. 


\section{Sometimes these identities are conflictual, possibly even contradictory, constantly in a process of change, malleable and tentative.}

Susan Griffin: "One can spend a whole life writing, . . and still hardly begin” (176).

Rosemary Sullivan: "A life is a puzzle to be decoded, but it is not a solution to the puzzle that one is after; it is an unlayering of the depths of the puzzle so that its mystery can be revealed. I think of the Spanish verb recordar: to remember, to pass back through the heart" (xiv).

Ursula Kelly: "The attention to ambiguity, paradox, and difference-more complex and subtle renderings of experience-is libratory, in itself (51).

\section{NO LOCKS}

in my mother's house

doors had no locks

or we forgot to use them, preferred, Can I come in?

the walls were thin like ice on autumn morning puddles

no insulated world

the house never silent

the telephone rang

always TV glared

the radio chattered

records tapes blared

a little house

no space to hide in

no attic no garage

no storage shed

no hallway no porch

no upstairs downstairs

always somebody

dropping in

framed in the doorway

with jackets and boots on

No, b'y, I can't stay, just

wanted to see how you were doin'

oil furnace cutting in and out

steady hum in the long winter

the wringer washer twisted

a boiler of oil for chips gurgled 
the refrigerator murmured

the fluorescent lights whined

clocks clicked

plumbing sluiced

always somebody going

and coming like a train station

like Tip the dog and his lover Ringo

who thought she lived with us

Skipper said, What are we doing, heating up all Lynch's Lane?

everybody talked, all the time

at the same time

whether heard or not

performed soliloquies

a dramatic troupe

with kindled hearts

Skipper sang country and western

my brother impersonated TV stars

my sister was a feminist comedian

Nan improvised like Marlon Brando

I wanted to be Frank Capra

Carrie was the live audience

cars spun up Lynch's Lane fast

in order to keep traction

stones spinning

the mill steam whistle moaned

winter played the house

like a percussionist

the house always sweltering

summer night respite in the backyard

spring rain whistled

autumn wind teased

rhythms no poet could name

the house alive, breathed

people always calling to one another

always a sense of being watched

so close, smiling simultaneously 
counterfeit and whole-souled

Carrie said, People lived close together

then, we'll never have that again

like she meant it,

like she missed something

LINE THREE: POSTMODERNISM PROMOTES THE INTERCONNECTIONS BETWEEN TRUTH AND FICTION.

Too often we use language to declare and assert and prove and argue and convince and proclaim notions of "truth."

But what happens if we emphasize the performative activity of language to question and play and savour and ruminate on notions of "truth"? Language as performance invites interactive responses, intellectual, emotional, spiritual, and aesthetic responses.

Brenda Marshall: "we give up the luxury of absolute Truths, choosing instead to put to work local and provisional truths" (3).

Jane Rule: "Autobiography is not easier than fiction.... It takes a rare, dispassionate intelligence to see the self from outside, a rare, compassionate intelligence to see others from inside. A willingness to be honest is not enough for those who have lied to themselves for so many years that they have come to believe the images of themselves they have created" (32).

Ursula Kelly: "Neither does such an approach constitute a rejection of the possibility of truth.... Truth is multiple - and always ever partial. Unsettled notions of what constitutes the personal, self, memory, history, and truth do, however, create the grounds for a more critical and reflective auto/biographical practice" (66).

\section{VERNA TIBBLE}

Last night Carrie called, Harry Tibble died.

He was repairing his roof, died with a hammer in his hands.

Ready to shingle heaven now.

Poor fellow, you remember Harry.

Four, five years ago

Harry's wife Verna spent

all their life savings,

nobody knows how much,

on BINGO and lottery tickets.

She wasn't lucky. 
She told Harry. The next day she drove to George's Lake,

pinned the car keys to her coat, nobody knows why,

and jumped through the January ice.

At the funeral, I said all I could say,

Harry, you must feel some awful.

Harry said, I just can't understand it.

How could Verna do it? How could

Verna spend all that money?

Last night Carrie whispered,

If Verna had kept her secret,

just a few more years,

Harry would never have known.

LINE FOUR: POSTMODERNISM PROMOTES DISCOURSE AS PERSONAL AND POLITICAL.

Life writing acknowledges how each one of us is written by many others.

In my life writing

I do not seek a factual record.

I want evocation, a rendering,

a performative space

where stories can be conjured out of memory imagination heart.

I want others to catch

the spirit of possibilities

in the alphabet,

to read my words

and know their words,

to read my stories

and know their stories,

to know how writing

transfuses translates transforms

life lives living liveliness.

Brenda Marshall: "The postmodern moment is an awareness of being-within, first, a language, and second, a particular historical, social, cultural framework" (3).

Ursula Kelly: "While poststructural theories may de-center the subject, the importance of the subject as a central point of transformation is not lost but reinscribed with, I would argue, greater political potential.

Herein is the project of poststructural auto/biography" (49).

Paulo Freire: "As I speak with such hope about the possibility of changing the world, I do not intend to sound like a lyrical, naïve educator.... I recognize reality. I recognize the obstacles, but I refuse to resign in silence or to be reduced to a soft, ashamed, skeptical echo of the dominant discourse" (58).

\section{GRADE FOUR GEOGRAPHY}

(for Aaron) 
In grade four geography

I read about

Bunga the Pygmy

who lived in Malaysia,

and other children, too,

tucked away in faraway

corners of the earth:

the steppes of Russia,

the savannahs of Africa,

the outback of Australia.

In grade four geography

I saw illustrations

of ten-year-old children;

for all their differences

they looked the same:

like Barbie dolls

with interchangeable costumes.

In grade four geography

I memorized enough

lists and facts

to colour the earth.

For example, what foods

did Bunga the Pygmy eat?

Mostly yams.

In grade four geography

I knew the earth

was an object,

solid, stable, static,

easily described,

the earth present

in the words

and pictures and maps

of my textbook.

In grade four geography

I learned about Bunga

the Malaysian Pygmy

who ate yams,

but I never learned

what Bunga learned

about Carl the Newfoundlander

who ate the tongues

of cod dipped

in milk, rolled

in flour, grilled,

light brown, crisp.

In grade four geography

I never saw Bunga

looking back at me, 
perhaps asking,

How can he eat

those tongues?

\title{
LINE FIVE: POSTMODERNISM PROMOTES UNDERSTANDING AS FRAGMENTED AND KNOWLEDGE AS PARTIAL.
}

\author{
Because the art and the heart of story-making \\ are capacious and uncontainable, \\ always seeking surprising twists and twisted surprises, \\ the story is a neverending story, \\ a story only temporarily suspended \\ with "once upon a time" \\ and "ever after." \\ There are many possibilities in any story. \\ I write and rewrite, \\ revise and revisit many possibilities.
}

Ursula Kelly: "What poststructural theories forewarn of is how...to tell one story is to silence others; to present one version of self is to withhold other versions of self" (51).

Rosemary Sullivan "To write a biography, then, is to write a metaphysical detective work: looking for the clues to a life" (xiv).

Brenda Marshall: "One thing that all this 'awareness' means is that as thinkers we need to hold in our minds a space for interpretations that are other than ours" (188).

\section{LOST MOTHER}

May March once lived alone in a shack of tar paper mill-cloth felt at the top of Lynch's Lane in a triangle of tall grass roseroot and dandelion lined by fences of neighbours who couldn't remember who owned the wedge of land or how May March came to be there

alone she spelled tales of husbands stolen to groves of witch-hazel where she conjured a moss child fairied away, years away, no one knew where, till one day he tracked his way back in a summer blue suit with sheila's brush erasing the lane in still another winter burst, and the lost son of May March asked Nan for his mother

with each question Nan's eyes

watered as if whipped

with a blasty bough,

I don't know, my boy, and May March's son said, 
ma'am, you don't know much,

and Nan whispered, most

of the time I just make stuff up, but this day I wish only I knew

how we lost your mother

\section{LINE SIX: POSTMODERNISM PROMOTES CRITIQUE, INTERROGATION, AND RESISTING CLOSURE.}

Life writing is always surprising me, unfamiliar flashes in the familiar, holes opening up like portals to disclose vistas never visited.

Brenda Marshall: "Neither innately positive nor negative, postmodernism is an opening, a space created for a particular awareness, interrogation" (193).

Ursula Kelly: "Seizing the importance of re-presenting and re-writing our selves as we reconstruct our visions of world communities entails deconstructing the stories we tell (of) ourselves and the desires that inform them" (49).

Paulo Freire: "Critical acceptance of my inconclusion necessarily immerses me in permanent search. What makes me hopeful is not so much the certainty of the find, but my movement in search. It is not possible to search without hope, not even in solitude" (106).

\section{FAMILY TV}

TV fathers sipped martinis at day's end, wore suits to work, solved all problems with quick quiet words, and lived in rooms of their own: studies dens rec rooms bedrooms with single beds where they wore pajamas

TV mothers read thick novels under bedside lamps after sipping percolated coffee all day, mostly sat around with other mothers talking about the mothers who weren't sitting with them sipping percolated coffee all day

watching TV

I wondered

who I could be

in another family 


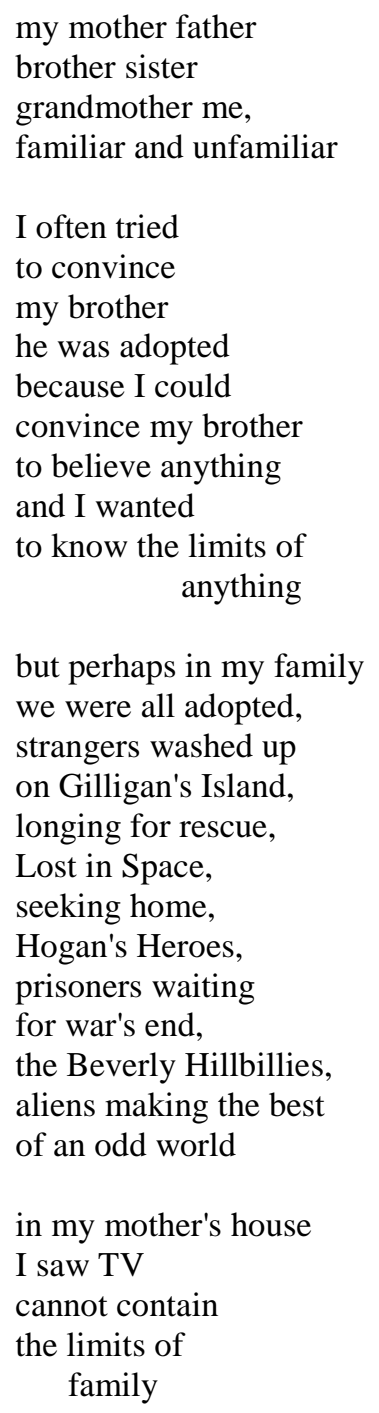

In my life writing I enter into an intertextual relationship with a discourse community, a world of textuality, where my voice re/calls or convenes the voices of absent predecessors and present presenters, our voices calling to one another, echoing one another.

Jacques Derrida: "Above all it is necessary to read and reread those in whose wake I write, the 'books' in whose margins and between whose lines I mark out and read a text simultaneously almost identical and entirely other" (4). 
The Preacher: "Of making many books there is no end" (Ecclesiastes, 12:12).

Michel Foucault: "When language arrives at its own edge, what it finds is not a positivity that contradicts it, but the void that will efface it. Into that void it must go, consenting to come undone in the rumbling, in the immediate negation of what it says, in a silence that is not the intimacy of a secret but a pure outside where words endlessly unravel" (22).

\section{TRUE ROMANCE}

on Lynch's Lane I had many heroes daily watched John Wayne Matt

Dillon the Lone Ranger Tonto Roy

Rogers Trigger Huckleberry Hound the Cartwrights Fred MacMurray

Hogan's Heroes Maxwell Smart Tarzan

Walt Disney Rin Tin Tin Lucy Ed

Sullivan Jed Clampett Quickdraw

McGraw Number 99 Batman Gordon

Pinsent the Cleavers Bugs Bunny

right a wrong world

and I needed heroes with the mad Mercers out the living room kitchen bedroom windows Mercers watching everywhere round us like sharks after old man Mercer divided his strip from Harbour to Heights divided it in parcels big parcels for the sons little parcels for the daughters and went away to shoot a moose and never came back

leaving Billy Mercer sitting

in the dark watching black and white television through sunglasses

afraid of ultraviolet rays

and Lil Mercer who hid in her house all winter but danced naked in her front yard under the full May moon and spent summer on the fifth floor of the Western Memorial Regional Hospital

and Sam Mercer on his verandah drinking rum watching the world go by wondering where the world was going since he'd never gone further than he could see from his verandah

and Sal Mercer who talked without end and never said a word I can remember using words to fend off the darkness the terrible darkness around her 
and Dougie Mercer who survived polio tuberculosis diabetic comas cancer for more than eight decades with words like talismans you don't have to worry about me I won't be here much longer

and Sylvie Mercer who spent her widow's pension on gifts for the neighbours a steady stream of Avon and Pot of Gold chocolates like a Kwakiutl or Doukhobor protesting no earth-licking fondness for possessions going even one better than Jesus by giving away her only coat

and I grew up reading True Romance left in the bathroom by Carrie who spun romance out of movies and magazines from Tom's Store while baking bread and jam jams and pushing wet laundry through the finger-crushing wringer and listening to the stories of her neighbours like a radio hotline host and serving french fries to sons who thought her kitchen was a take-out

and I grew up waiting for Skipper who always woke early with dark still filling the windows and walked alone to the mill through the warm hot cool cold seasons and all day inhaled the heat and noise of the world's biggest paper mill his laughter still heard over the endless pulse of machines and at day's end burst into the kitchen chased by the dark his face a grin

and I grew up with Carrie and Skipper at the center of Mercer madness listening to Sal while Billy watched television and visiting Dougie and Lil in the hospital and sitting on the verandah with Sam and delivering Sylvie's gifts to the neighbours and often I asked Carrie and Skipper why do you put up with them their only reply they're family and on television I saw Neil Armstrong walk on the moon and I know it is true even though Billy Mercer still claims 
it was all a hoax

KNOWING THE CONNECTIONS BEYOND BEGINNING AND ENDING:

\author{
Located in the earth, \\ knowing the heart, \\ I will learn by heart \\ the earth's rhythms, \\ rooted in humility \\ for forgetting and forgiving, \\ rooted in courage \\ for remembering and giving.
}

\title{
References
}

Derrida, Jacques. Positions. Trans. Alan Bass. Chicago: U of Chicago P, 1981.

Foucault, Michel. Maurice Blanchot: The Thought from Outside. Trans. Brian Massumi. New York: Zone Books, 1990.

Freire, Paulo. Pedagogy of the Heart. Trans. Donaldo Macedo and Alexandre Oliveira. New York: Continuum, 1997.

Griffin, Susan. The Eros of Everyday Life: Essays on Ecology, Gender and Society. New York: Doubleday, 1995.

Heidegger, Martin. Poetry, Language, Thought. Trans. Albert Hofstadter. New York: Harper and Row, 1971.

Kelly, Ursula A. Schooling Desire: Literacy, Cultural Politics, and Pedagogy. New York: Routledge, 1997.

Leggo, Carl. Growing Up Perpendicular on the Side of a Hill. St. John's: Killick Press, 1994.

Leggo, Carl. View from My Mother's House. St. John's: Killick Press, 1999.

Marshall, Brenda K. Teaching the Postmodern: Fiction and Theory. New York: Routledge, 1992.

Milosz, Czeslaw. The Witness of Poetry. Cambridge: Harvard UP, 1983.

New International Version of the Holy Bible. Grand Rapids: Zondervan Bible Publishers, 1978.

Nichol, bp. An H in the Heart: A Reader. Toronto: McClelland and Stewart, 1994.

Rule, Jane. A Hot-Eyed Moderate. Toronto: Lester \& Orpen Dennys, 1986.

Sullivan, Rosemary. Shadow Maker: The Life of Gwendolyn MacEwen. Toronto: HarperCollins, 1995.

Woolf, Virginia. A Letter to a Young Poet. London: Hogarth Press, 1932. 
Biography

Carl Leggo is a poet and Associate Professor in the Department of Language and Literacy Education at the University of British Columbia. 